Lordship and Environmental Change in Central Highland Scotland c.1300-c.1400

Richard Oram $^{1}$ and W. Paul Adderley ${ }^{2 *}$

1 Centre for Environmental History, University of Stirling, Stirling FK9 4LA, Scotland U.K.

2 School of Biological and Environmental Sciences, University of Stirling, Stirling FK9 4LA, Scotland U.K.

r.oram@stir.ac.uk

+441786 467584

w.p.adderley@stir.ac.uk

+441786 467861

* Corresponding author 


\title{
Lordship and Environmental Change in Central Highland Scotland c.1300-c.1400
}

\author{
Richard Oram $^{1}$ and W. Paul Adderley ${ }^{2}$ \\ 1 Centre for Environmental History, University of Stirling, Stirling FK9 4LA, Scotland \\ U.K.
}
2 School of Biological and Environmental Sciences, University of Stirling, Stirling FK9 4LA, Scotland U.K.

r.oram@stir.ac.uk

w.p.adderley@stir.ac.uk

\begin{abstract}
Whilst there has been an increasing recognition of the influence of natural agency on human society in Scotland in the medieval period, conventional historiography has generally presented the wholesale reconfiguration of structures of secular lordship in the Scottish central Highlands in the $14^{\text {th }}$ century as an essentially political consequence of the sociopolitical dislocation associated with the Anglo-Scottish wars that occurred after 1296. The establishment within the region of militarised Gaelic kindreds from the West Highlands and Hebrides of Scotland has come to be regarded as either a symptom of efforts by externally based regional lords to bolster their authority, or an opportunistic territorial aggrandisement by newly dominant neighbouring lords. Feuding and predatory raiding associated with these kindreds is recognised as competition for resources but generally in a context of projection of superior lordship over weaker neighbours. Evidence for long-term changes in climate extrapolated from North Atlantic proxy data, however, suggests that the cattle-based economy of Atlantic Scotland was experiencing protracted environmentally-induced stress in the period c.1300-c.1350. Using this evidence, we discuss whether exchange systems operating within traditional lordship structures could offset localised and short-term pressures on the livestockbased regime but could not be sustained long-term on the reduced fodder and contracting herd sizes caused by climatic deterioration. Territorial expansion and development of a predatory culture, it is argued, were responses to an environment-triggered economic crisis.
\end{abstract}

Keywords: Climate change, Territorial expansion, Winter temperatures, Summer Temperatures. 


\section{Context and Introduction}

One general feature of the historiography of later medieval Scotland is recognition of a major restructuring from the mid-1300s onwards of social organisation and political power in the Highlands and Islands. The main dimension of this change has been presented in terms of the rise of Clann Domhnuill, and by lesser kindreds like the Mackintoshes and Clann Donnchaidh or Robertsons (Brown 2004:332-333). The heads of these kin groups are described as developing from the 1330s as 'predatory and independent leaders of militarised followings ready to exploit a period of disorder and fragmentation' (Brown 2004:332). The context for their emergence (Figure 1), it is argued, was the protracted period of war, disease and climatic deterioration that started in the 1290s; with some scholars adding the effects of these predatory war-bands to the combined impact of declining population and falling arable production in upland zones as major factors behind the growing inability of lay and ecclesiastical landholders from outside those areas to exploit them profitably. This position was aggravated by the collapse of the structures of authority which had formerly protected and enforced the rights of these landholders, for the period had witnessed the disintegration of the established political edifice, principally the complex of Highland lordships controlled by the Comyns and MacDougalls. Others, however, benefited from this situation; Highland and Hebridean kindreds who based their economies on non-arable agriculture, principally cattlerearing, and predation on their neighbours, have been regarded as cushioned from the impact of climate change and population decline and best positioned to capitalise on the political instability. The predatory culture of these kindreds arose from the existence within them of bands of armed retainers who formed the retinues of the heads of kin. Such warrior bands were known as ceatharn and their emergence represented the militarisation of the Highlands (Brown 2004:332).

The basis of possibly similar later medieval military retinues in Ireland were the buannachan, mercenaries in the employ of regional lords that were billeted amongst the local populace and maintained through Gaelic Irish rulers' rights to buannacht, a mechanism available to them from at least the $11^{\text {th }}$ century (Simms 2000:131). There is no unambiguous pre-14 ${ }^{\text {th }}$-century evidence for the operation of such billeting mechanisms in the Scottish Gàidhealtachd, reference to it there occurring only in a late, poetic, and possibly antiquarian source. A lord's right to extract overnight board and lodgings for his officers, referred to as sorthan or sorthen 
in Irish Gaelic, is known from a handful of Scottish 14th-century sources (where it occurs as sorthyn or sorran), all apparently from Galloway rather than the Highlands, which are clearly delimiting obligations and dues which had attached to the land in question in the $13^{\text {th }}$ century and probably earlier. (Thomson 1882: xiii-xiv; Croft Dickinson 1960: 173-4). This right, however, was clearly neither designed nor intended for the support of large numbers of warriors and the later 14th-century references to this mechanism appear at pains to curb its over-use and abuse by lords (Thomson 1882: no.192). Nevertheless, some form of support structure for large military retinues possibly existed in Gaelic Scotland by the $12^{\text {th }}$ century, when West Highland warlords are recorded as leaders of bands of mercenary warriors in the service of Irish kings (Duffy 2007:1-23).

Within a Scottish context, the opportunities to support these warriors through predatory activities had been drastically curtailed in the $13^{\text {th }}$ century by the growth of effective royal authority within the Highlands and Islands. The principal mercenary kindreds had been successfully absorbed into the Scottish polity and the foremost lords, like the MacDougalls of Lorne, became barons under the Scottish crown (MacDonald 1997). Opportunities for wealth generation through mercenary service or plundering raids within Scotland had ended, leaving the kindreds with the burden of supporting their otherwise non-productive warrior bands on their own territorial resources or through operations outside of the sphere of the Scottish crown, most obviously in Ireland. The increasing use by Gaelic Irish lords of mercenaries of largely Scottish Hebridean and West Highland provenance, referred to from at least the 1290s as gallóglach (anglicised as galloglass) (Duffy 2007: 1, Nicholls 2007), lies beyond the scope of this present paper and remains the subject of ongoing research (Duffy 2008, 2007), but it is important to note that these Scottish mercenaries appear already to have been organised on the basis of militarised kindreds in the $13^{\text {th }}$ century if not before (for the activities of one of these kindreds in the mid- $13^{\text {th }}$ century, the MacRuaidhri, see Woolf 2007).

Moves towards the fuller integration of the western Highlands and Islands into the administrative structures of the kingdom were instituted in 1293 (Brown et al. 2007). The plans, however, were stillborn casualties of the post-1296 Anglo-Scottish wars. Government and administration continued to rely instead on the personal authority of nobles to whom the king delegated authority, such as the Comyns in Badenoch and Lochaber or the MacDougalls in Lorne. By 1310, Robert Bruce had defeated both families and their wider alliance network in the central and western Highlands. Amongst other defeated and displaced kindreds of the 
Scottish civil wars were the Knapdale-based MacSweens or Clann Suibhne, who had already established a reputation as one of the leading providers of mercenaries in west mainland Scotland. They had been driven from Knapdale as early as 1301 by the Stewarts of Menteith (Oram and Ross 2006: 33; Bain 1884: no. 1255), in what appears to have been the expulsion of the kin leadership and their military retinue only rather than the wholesale departure of their tenants and other dependents. The military power of Clann Suibhne maintained its identity in exile and in 1310 was clearly still a sufficiently potent enough force to form the core of a campaign intended to wrest Knapdale from the Stewarts and defeat the allies of Robert Bruce whom he had ensconced in power in Argyll (Oram and Ross 2006: 34-5; Macpherson et al. 1814: 90b). Despite the failure of that campaign, Clann Suibhne remained a significant military force and, as the MacSweeneys, established themselves in Donegal and west Ulster as a key provider of galloglasses throughout the remainder of the Middle Ages (Simms 2007). The significant point, however, is that the case of Clann Suibhne demonstrates not only the existence of substantial military retinues in the Gaelic west mainland of Scotland in the late $13^{\text {th }}$ and early $14^{\text {th }}$ centuries but also the cohesion of such retinues around the figure of the head-of-kin and their ability to maintain that cohesion independent of a fixed territorial base. Provided they could impose themselves on a host territory or find themselves employment as mercenaries, they could become effectively selfsustaining entities.

Just as Clann Suibhne were replaced by the Stewarts of Menteith, so too did Robert Bruce set up an alternative focus for coercive power in the region once dominated by the Comyns, their kinsmen and allies in the central Highlands in the earldom of Moray which he created in 1312 for his nephew, Thomas Randolph. The new earl and his successors, however, lacked the close personal relationship and kinship bonds which had underpinned the authority of their predecessors. Instead of these traditional mechanisms for the articulation of authority, the Randolphs relied on the enhanced legal franchise of regality jurisdiction (Duncan, 1988). Regality powers enabled them to impose their lordship in terms of all-embracing and overriding legal authority but positioned them as effectively external agents who lacked a substantial personal presence in the region in terms of either demesne estates or bonds of blood. The effectiveness of that form of power can perhaps be seen in the record of the pursuit and killing of 50 transgressores by Earl Thomas's coroner and the display of their heads at Eilean Donan castle in c.1330 (Watt 1996:59). What crimes these 'lawbreakers' had 
committed is unrecorded and, although they are not so designated in the documentary record, it is tempting to see the transgressores as ceatharn.

It is not for a further half century before that term appears to have emerged into common currency in Scotland. From the 1380s, the Latin records of Scottish parliaments and general councils narrate measures to deal with complaints about katherani or ketherani, or 'caterans', as the Gaelic term ceatharn is rendered in modern English. Although the word was understood to refer to a warrior group, the manner in which these bodies dwelt on the illegality of the caterans' activities gave rise to a view of them as 'broken men' and 'Highland robbers' (Boardman 1996:64-83). What dominated complaints against them was the manner in which they were reported to occupy and enjoy lands to which they possessed no legal title and raided the property of neighbouring landowners. Yet, this image of the ceatharn 'as an ungovernable Highland bandit operating outside any recognisable form of authority' (Boardman, 1996:83) does not tally with contemporary records of their activities. Even the largely hostile Lowland chroniclers, Andrew Wyntoun and Walter Bower, present them most often in military situations, as in the 1391 conflict at Glen Brerachan between Duncan Stewart, son of Alexander Stewart, earl of Buchan, and Sir Walter Ogilvie, or the 1396 organised melee on the North Inch of Perth between chosen bands from the feuding confederations of Clan Chattan and Clan Qwhele (Watt 1987:7-9). Bower presents the Perth incident in terms of widespread disturbance 'of the north of Scotland beyond the mountains' (Watt 1987:7), which he sets into the more general context of Highland lawlessness against which successive parliaments and councils had fulminated since the 1380s.

The earliest surviving legislation relating to caterans dates from November 1384 and lies amongst a raft of acts directed against 'disorder' in the Highlands (Boardman 1996: 130-133). Significantly, however, it did not legislate against the institution per se but against men who acted 'in the manner of a cateran' (Latin katheranatu) (Brown et al. 2007). This initial act was followed in April 1385 by a decree that complained 'of the lack of justice in the highland and northern regions, because many malefactors and caterans wander, dwell and are received there, who lay waste and exhaust both the clergy and the people by savage killing, pillaging and burning' (Brown et al. 2007). The main complaint was that these bands were not simply raiding in these territories but were settling and being received there. The political geography and socio-political structures of Highland Scotland were being reconfigured. 


\section{Environmental Change in Central Highland Scotland}

In addition to information gathered by examination of historical sources, proxy environmental measures may be used to gain a long-term perspective on past climate which may offer context for these social reconfigurations. Stimulated by the present-day discussion on global climate change many advances in understanding palaeoclimate records have been made using a variety of different proxies including ice-core, ocean sediment and tree-ring data. Many of these data are considered region-specific and a synthesis of different data can been undertaken in order to understand climatic changes both over wider spatial areas and longer temporal periods. Since the western margins of the British Isles experience a temperate maritime climatic regime, there is likely to be considerable buffering of long-term climatic shifts by the North Atlantic Ocean, however year-on-year seasonal differences i.e. summer vs. winter have been demonstrated to have had a significant impact on landscape management in other North Atlantic locales including Iceland (Adderley et al. 2008, McGovern et al. 2007, Simpson et al. 2002), Faroe Islands (Adderley and Simpson 2005, Edwards et al. 2005) and southern Greenland (Adderley and Simpson 2006). Such climatic variation has previously been considered for various upland areas of the United Kingdom from historical data (Parry 1985:351-367).

In respect of the climate for the period $1300-1400$, there are limited numbers of climatic proxies that have been resolved to annual or seasonal resolution. Furthermore, these are located over a wide geographic range across the northern hemisphere. The approach taken is therefore to contrast Northern Hemisphere/North Atlantic summer temperatures from dendrochronological analyses (Figure 2a) (see Briffa, 2000; Briffa et al., 2001), stable isotope records providing an index of relative winter "severity" (see Adderley and Simspon 2006) from ice core data (Figure 2b) and for an annualised long-multi-proxy mean (Figure 2c). It is clear from the annualised multi-proxy data that there was a considerable change in northern hemisphere temperatures from around 1300 towards colder annual temperatures. This marks the "end" of the so-called medieval warm period, a period where in addition to generally higher mean temperatures, the winter and summer temperatures appear to vary independently. The summer and winter temperature indicators from Ural and Siberian tree-ring data and from the Greenland Ice cap respectively are, obviously, distant to the United Kingdom context and must be interpreted cautiously. There is however a clear co-incidence in reduced winter and 
summer temperatures from AD 1300 for c.30 years suggesting that an abrupt and prolonged cold period may have been experienced across the North Atlantic. The cumulative effect of these cold periods over many years is likely to be more pronounced than shorter periods of year-to-year variation.

\section{Historical Evidence for Effects of Climatic Change}

How did that cumulative effect manifest itself in Highland and Hebridean Scotland? Scottish chronicles are less detailed than other contemporary records for the impact of climate change and famine, such as have been explored in detail by William Chester Jordan in the context of the so-called 'Great European Famine' of 1315-22, or more recently by Bruce Campbell for 14th-century England (Jordan 1996; Campbell 2008). Nevertheless, in the later $14^{\text {th }}$-century compilation of earlier chronicle material attributed to John of Fordun, ${ }^{1}$ it is described how in 1310 (probably misdating a 1315-6 event) 'so great was the famine and dearth of provisions in the kingdom of Scotland that, in most places, many were driven, by the pinch of hunger, to feed on the flesh of horses and other unclean cattle' (Skene 1872:338; Broun 2008: 50-53). Fordun, or possibly an earlier $14^{\text {th }}$-century contributor to the compilation that traditionally bears Fordun's name (Penman 2004: 56-7), also noted how in 1321-2 'there was a very hard winter, which distressed man, and killed nearly all animals' (Skene 1872: 338). These incidents tally well with the palaeoenvironmental record (Figure 2) and point to sustained climatic disturbance which saw the growing season in parts of the country shortened by about a month (Morrison 2001:100). The main effect of that shortening is commonly linked to increasingly frequent harvest failures and a decline in both grassland and arable production generally; a perspective rooted in acceptance that a cereal-based diet was the medieval socioeconomic norm. The notion that non-arable based, livestock-rearing societies were somehow less affected by weather events and climate change is a questionable premise and has been driven principally by the almost overwhelming focus of studies of the early $14^{\text {th }}$-century crises on arable productivity. Likely impacts on Scotland have been presented in generalised statements founded chiefly on extrapolation from English records.

One of the earlier sources preserved in Fordun's collection drew a sharp contrast between the primarily cereal-producing arable lowlands and the less fertile uplands. It described the uplands as 'very hideous, interspersed with moors and marshy fields, muddy and dirty; it is however, full of pasturage grass for cattle, and comely with verdure in the glens, along the 
water-courses' (Skene 1872:37). Such generalised descriptive contrasts, coupled with a modern perception of thinly-spread population based on post-Clearance levels, has established a notion of the Highlands' relative insulation from the worst consequences of crop-failures in the early $14^{\text {th }}$ century. The region, it is suggested, had ample dairy products and meat to cushion the blow of any failure of the cereal harvest. What this argument ignores is that the climate affected all vegetation growth, not just cereal crops. A shortening of the growing season by around a month meant that grass growth on summer pastures in upland districts began later in May and ended earlier in September. Nor could the pastures bear grazing across the whole of that shortened period and it is possible that the summer pasturing of cattle at upland shieling locations was reduced to around four months in the year.

Furthermore, the biomass produced was incapable of sustaining the numbers of animals that had been summered on these pastures during the Medieval Warm Period. Coupled with this factor was the probable reduction in the altitudinal range of grazing, as the more extreme weather conditions lowered the altitude at which both crops could be grown and pastures exploited productively (Parry 1975:5-11, Tipping 2004; 1999; 1998). Even at present, the height range of improved land in most of north-western Scotland barely exceeds $100 \mathrm{~m}$ (above Ordnance Datum). The pressure, however, was not limited only to the higher altitude summer grazing, for the reduced growing season also had an impact on hay production in low-level meadows, diminishing supplies of winter fodder, while winter grazing generally was placed under great strain as herds had to be pastured on them for longer periods each year. A further factor to be considered is the actual effect of the extreme weather on the physical condition of the livestock. Sustained periods of high winds and rain cause sheep and cattle to lose body-heat and use more calories, thus preventing them from accumulating the body-mass wanted for meat-production or the fat reserves to aid them through the winter. Calorie consumption to maintain body-heat, moreover, reduced production of milk needed both for feeding calves and lambs and also for dairy products. For a culture dependent primarily upon cattle, the consequences of a sustained period of climatic deterioration were dire.

Added to this record of a climate-driven crisis in biomass production to support livestock was a second environment-related catastrophe affecting both cattle and sheep. In 1319, a murrain affecting cattle, now identified as probably a viral disease akin to rinderpest, spread into south-eastern England from continental Europe (Spinage 2003: 92-3). By the summer of 1319 it had already reached the Anglo-Scottish border regions and by 1321 was reported as 
affecting the whole of the British Isles (Kershaw 1973: 14-14). Mortality levels amongst cattle and oxen in some areas of England seem to have exceeded 90 per cent (Spinage 2003: 93) and in Ireland the disease, which was referred to in the Annals of Ulster as the 'cowdestruction' appears to have devastated herds in two episodes in 1321 and 1324-5 (Kershaw 1973: 14). Bruce Campbell has recently estimated that the impact upon the national demesne herd in England was a drop to around 50 per cent of the pre-murrain figure (Campbell 2008). We have, unfortunately, no comparable data for Scotland, but the lamentation of the Irish chroniclers suggests that similar mortality levels may have been experienced. This culling, however, was followed in England by a recovery to around 70 per cent of the pre-1319 level by 1323 which, if similar a recovery was staged in Scotland, would suggest that any mitigation of the pressure on grazing through the cattle mortality of 1319-21 was relatively short-term. To what extent any greater recovery towards pre-murrain stocking levels was a consequence of reduced grazing opportunities remains unknown. The important consideration is that an economy and society founded on cattle was clearly under major stress by the early 1320 s.

Some modifiers need to be introduced into the image of unmitigated crisis. There is a deepseated view in the traditional historiography of pre-Improvement agricultural regimes in Scotland that hay-making and the storage of winter fodder for livestock was rare generally and in the Hebrides and western Highlands was an innovative development of the later $18^{\text {th }}$ century (McCormick 1998). Records of high levels of mortality in over-wintered stock in the later $17^{\text {th }}$ and $18^{\text {th }}$ centuries are commonly cited, usually supported by graphic examples of anecdotal testimony. Great caution needs to be exercised in using these accounts, however, as many were produced in reports with strong pro-Improvement agenda, and even greater caution should be used when any attempt is made to project the circumstances reported in such literature back into the Middle Ages. It is, for example, very difficult to correlate the image of low over-wintering survival and the poor springtime condition of the livestock with the record of a substantial cattle-drove trade out of the Highlands and Hebrides already in existence in the $16^{\text {th }}$ century and perhaps earlier. Equally problematical is the view of traditional agricultural practices in the Highland zone as lacking in development of haymaking and winter fodder provision for stock. The abundance of dail place-names throughout the former and present Gàidhealtachd, a generic term applied to rich grassland watermeadows from which hay was obtained and where seasonal grazing for cattle could be provided, coupled with prominent reference to these subjects and to service obligations of 
winning and leading hay, provision of hay as feed for stock in upland districts and the keeping of fodder in hay-yards in surviving estate rentals from the late $15^{\text {th }}$ century onwards (Rogers 1880: vol i 172; vol ii 95-96; vol ii 168, 183-185, 261), suggests an altogether more favourable picture than is presented by the Improvement literature. This more positive view, however, also needs to be tempered with recognition that the regime reflected in the rentals appears to be one where hay and winter fodder may have been largely reserved for the flocks and herds of the landlords, with the tenants supplying the commodity but having little of it to support their own livestock.

\section{Discussion and Conclusions}

What were the likely consequences of a sustained episode of environmental stress? A $15-20 \%$ reduction in the growing season on the economically vital summer grazings translates to about a $25-30 \%$ reduction in the carrying-capacity of that land. Economic response models of the impacts of a deterioration in conditions for arable and fodder production for pre-modern Iceland and elsewhere suggest that prolonged periods of moderately poor growing seasons are more damaging than smaller numbers of more extreme climatic downturns (McGovern et al. 2007); and that different responses may ensue. In this instance, the responses to a deterioration in stock conditions may first have seen efforts to increase numbers to make up for shortfalls in volume of meat and milk being produced, but it would have been evident quickly that all this strategy was producing was more ill-nourished animals and possibly a higher mortality level amongst them. It was possibly out of these circumstances that the strategy of calf-slaughter that appears to be well represented in the archaeological record was adopted (McCormick 1998: 49-51). A second response may have been a reassessment of souming levels, the estimates of carrying-capacity of the grazing which were applied throughout medieval Scotland (Ross 2006). Stock numbers consequently would have been drastically reduced, with the main impact being seen at the lower end of the social spectrum where tenants of lowlands-based landlords who operated a rent-based exploitation regime became less capable of meeting their obligations. Highland nobles who maintained their position on cattle rendered by their tenants and which perhaps they used also to support warbands and project their status through lavish feasting, were also badly affected. By the 1330s, therefore, traditional lordship structures were under severe economic pressure and the established mechanisms for support of military retinues strained to breaking-point. Shortterm, the exchange system which sustained the ideology of behaviour and display (Dodgshon 
1998: 14-15), of which the buannachan in Ireland and their equivalent in Scotland were perhaps a part, could off-set shortages through redistribution of resources received as renders from tenants. Longer term, however, such a policy was unsustainable as the renders formed essential elements in secondary circuits of exchange, for example supporting prestige craftsmen who supplied the social elite with high-status commodities, and in projecting the image of wealth and power of the lord through material and social display, including the maintenance of complex households. For Highland and Hebridean nobles, the choice was either to reduce expenditure on such activities and suffer the consequences of diminished prestige, or find alternative sources of income.

For some of the greatest kindreds, like Clann Domhnuill, territorial expansion as a means of offsetting economic retrenchment in a time of environmental change was a viable option. Their fortuitous backing of the Bruce cause after 1307 resulted in substantial gains in the southern Hebrides and SW Highlands. Clann Domhnuill's indispensability to both Bruce and Balliol families after 1332 permitted further rapid growth in mainland and island districts. Further expansion came where opportunity allowed and by the later 14th century, the decline of English power in north and west Ulster, coupled with increasing mercenary opportunities within Gaelic Ireland more generally, had also seen segments of Clann Domhnuill established in Antrim (Kingston 2004, 1999). Cadet branches or septs, and dependent kindreds like the Macleans and Camerons, were established on the territorial acquisitions, chiefly in Lochaber and the Inner Hebrides. Other kindreds with significant military followings capitalised on the demand for military muscle from nobles who were seeking to consolidate their power in the central Highlands. What is unclear, however, is if these warbands were already a common feature of traditional Gaelic lordship in the central Highlands before the $14^{\text {th }}$ century or if they represented the eastward spread of western Highland and Hebridean kindreds in response to favourable political and economic conditions. The fact that by the middle of the $14^{\text {th }}$ century, however, major indigenous kindreds from this area seem already to have had the ability to field substantial military retinues as mercenaries in the service of external lords suggests that such warbands were an already-established feature of Gaelic lordship in the region. Thus in Atholl after 1342, Clann Donnachaidh provided warriors for Robert Stewart, the future king, and from the late 1360s along with Clann Chattain aided his son, Alexander Stewart, to consolidate his grip in Badenoch and to overawe his neighbours in Moray and Aberdeenshire (Oram, 1999: 205-206). To maintain these warbands, their employers imposed them on their own tenants and, if they did not actually encourage them to forcibly quarter themselves on the 
tenants of their neighbours equally they did not have the ability to prevent them from so doing. This development may have involved a straightforward expansion and abuse of a lord's right to free quarters and living at free expense for his officials and servants, like the example of sorryn in Galloway, which the very limited charter evidence does imply was deeply resented and was one of the factors behind the parliamentary legislation from 1384 onwards (e.g. Thomson 1882: no.192).

One paradox of the apparently widespread availability and employment of these mercenary bands through the mid and late $14^{\text {th }}$ century is that there was evidently a continuing surplus in human resources within parts of Gaelic Scotland at a time when the European population generally was in sharp and prolonged decline as a consequence of the famine of 1315-22 and, from 1346/7, of the plague nowadays labelled as the Black Death. This apparent surplus in the adult male population raises a question of the impact of epidemic disease in the Highlands and of its potentially differential impact on highland and lowland zones generally. There are no hard quantitative sources such as exist for large parts of England and continental Europe to permit assessment of the impact of the Great Mortality of 1346-1353 within Scotland generally, let alone the Highlands. In 'Fordun', the only allusion to the scale of mortality is the observation that in 1350 'nearly a third of mankind were made to pay the debt of nature' (Skene 1872: 359). There is, likewise, no hard data for the impact of the plague on the Hebrides, with only a single, external account reporting that the disease had struck the Western Isles in 1348-9 but giving no indication of the numbers of dead (Benedictow 2004: 154). Nevertheless, despite this lack of clear evidence for the epidemic's effects on Scotland, it has been claimed that the Black Death 'appears to have been the worst disaster suffered by the people of Scotland in recorded history' (Grant 1984: 75). The collapse in values of property revealed in the land assessment of 1366 probably relates directly to a drastic fall in population levels and the consequent ending of around a century of upward pressure in rental values. The assessment of 1366 reveals that the drop in values affected all parts of the country, with those north of the Tay falling 44 per cent and those to its south by around 52 per cent (Grant 1984: 77-9). These figures suggests that upland rural populations, as predominated in the northern part of the country, were as adversely affected by plague as those in the potentially more densely settled lowlands. This situation runs against one view of Scotland's experience of the Black Death which has implied a potential differential in impact possibly related to a tendency towards dispersed settlement in the Highlands as opposed to more nucleated settlement in lowland areas but matches arguments advanced elsewhere for 
the experience of the country in $16^{\text {th }}$ - and $17^{\text {th }}$-century epidemics (Jillings 2003: 88-9; Oram 2008: 17-20, 32). What this collapse in population may have done, as argued by Grant, is simply heighten the pre-existing contrast between the economic systems prevailing in the more arable lowlands and pastoral highlands (Grant 1984: 201) and intensify the already existing emphasis in the latter on livestock as the measure of wealth.

Despite what, if we accept the generalised statements in 'Fordun' and later Scottish chronicles, was perhaps a drop in population of over 30 per cent in 1349-59 (Zeigler 2003: 169-170), the militarised kindreds as already existed in Highland Scotland were still seeking to maintain substantial bodies of warriors. The continued availability of such men may relate to what some scholars have identified as a class differential in mortality rates, with lay elites apparently faring better than commoners (Zeigler 2003: 170-171). Such a distinction is reported by 'Fordun', who claimed that 'this everywhere attacked especially the meaner sort and common people; - seldom the magnates' (Skene 1872: 359). It is possible that this differential was related to general health and diet (Grant 1984: 74), with the well-feasted and comfortably-accommodated warriors enjoying a better level of nutrition and lifestyle than the average man. That diet and lifestyle, however, would have been significantly threatened by the decline in general population and productivity which lies behind the 44 per cent fall in land values revealed in the 1366 land assessment.

Was this the final blow to traditional support mechanisms which triggered the development of the predatory activities linked to the ceatharn? Kindreds who maintained permanent warbands were placed under increasing pressure to find resources to sustain them, while lords who employed them faced identical pressures in finding the means to pay them. Increasing the burden on your own dependents was not a viable long-term solution for this problem: offsetting the burden through predation on one's neighbours was one alternative. This response may be another dimension of the intrusion of Clann Donnchaidh interest out of Atholl into central Strathspey in the 1360s, where local lords, whose main bases of operations were increasingly external to the district, lacked the means of effective resistance (Ross 2003: 1734). For employers of ceatharn using such men to consolidate authority in territory where they lack either established kinship links or a substantial landed base, it was an equally attractive solution, for it both off-loaded the financial burden of maintenance and augmented local perceptions of their power and authority. 
Alexander Stewart's regular use of this latter response was a key factor in his bitter disputes with Bishop Alexander Bur of Moray, and John Dunbar, earl of Moray, whose estates were subject to the depredations of Stewart's ceatharn. To protect their interests both Bur and Dunbar themselves entered into agreements with other kindreds (Boardman 1996: 84-85). Despite efforts to formally regulate the activities of these groups through contracts, between the 1380s and the early 1400s, as the climate sank into another round of colder and wetter weather with attendant crop failures and livestock losses, it was evident that the interests of the ceatharn and their erstwhile employers had largely diverged. Environmentally triggered economic pressure and demographic contraction continued to reduce local populations' ability both to pay rent and to maintain ceatharn. For Stewart, the decline in income which this climatic downturn triggered was perhaps more of a cause of his failure in the 1370s and 1380s to pay the rents he was due to the Bishop of Moray for the lordships of Abriachan, Bona and Rothiemurchus, or to his niece for Urquhart, than any arrogant belief that he could simply appropriate full property rights. To maintain the retinues on which his authority was founded, he needed to preserve if not extend his territorial resources, a need which became more pressing as climate change further reduced the value of his possessions. Failure to pay rents was one response to this problem, but the unleashing of his ceatharn onto the property of the men who were pressuring him was another. And to protect themselves, his victims secured the services of their own ceatharn who preyed on the territory of rivals. By the early 1400 s, such predatory lordship had become an established feature of the socio-economic structures of Highland Scotland.

Political circumstances after 1300 were certainly a major factor in the long-term destabilisation of society in Highland Scotland. The collapse of traditional structures of authority and the failure of the crown to provide adequate or enduring substitutes created conditions which other Gàidhealtachd-based nobles were well positioned to exploit. But political upheaval alone did not create the social stresses which emerged in the $14^{\text {th }}$ century. Those stresses were the product of the ending of the viability of the agricultural economic regime which had evolved across the Medieval Warm Period, upon which the edifice of social, political and cultural power and authority in northern and western Scotland was built, further compounded by the drastic decline in population caused by plague mortality in 134950 and subsequent epidemics through the $14^{\text {th }}$ century. Assigning greater significance to the role of environmental crisis in triggering fundamental social and political reordering has become something of a bandwagon in current historiography, but in the case of $14^{\text {th }}$ and early 
$15^{\text {th }}$ century Scotland we seem to have a clear-cut case of climate change and disease driving the processes of reconfiguration in the mechanisms which underpinned the economy and culture of clan-based Highland society. 


\section{Acknowledgments}

From the University of Stirling, the authors wish to thank Dr Alasdair Ross for comments on an earlier draft of the manuscript, and Bill Jamieson for assisting the production of figures. Paul Adderley kindly acknowledges the financial support of The Leverhulme Trust and of Research Councils UK. 


\section{Footnote}

${ }^{1}$ This is not the place to engage in a detailed discussion of the sources of 'Fordun'. For explorations of the issues involved see Broun, 2008; 1999. 


\section{Literature Cited}

Adderley, W.P., Simpson, I.A., Vésteinsson, O. 2008. Local-scale adaptations: A modeled assessment of soil, landscape, microclimatic, and management factors in Norse home-field productivities. Geoarchaeology 23: 500-527.

Adderley, W.P., and Simpson, I.A. 2005. Early-Norse home-field productivity in the Faeroe Islands. Human Ecology 33: 711-736.

Adderley, W.P., and Simpson, I.A. 2006. Soils and Palaeo-climate based evidence for past irrigation requirements in Norse Greenland. Journal of Archaeological Science 33: 16661679.

Bain, J. (Ed.). 1884. Calendar of Documents Relating to Scotland, vol. 2. H.M. General Register House, Edinburgh, UK. 714 pp.

Benedictow, O.J. 2004. The Black Death 1346-1353. A Complete History. Boydell Press, Woodbridge, UK. 433 pp.

Boardman, S. 1996. The Early Stewart Kings. Robert II and Robert III, 1371-1406. Tuckwell Press, East Linton, UK. 348 pp.

Briffa, K.R. Osborn, T.J., Schweingruber, F.H., Harris, I.C., Jones, P.D. Shiyatov, S.G. and Vaganov, E.A. 2001. Low-frequency temperature variations from a northern tree ring density network. Journal of Geophysical Research 106 D3: 2929-2941.

Briffa, K.R. 2000. Annual climate variability in the Holocene: Interpreting the message of ancient trees. Quaternary Science Reviews 19:87-105.

Broun, D. 2008. Attitudes to Gall and Gaedhel in Scotland before John of Fordun, available online at http://www.arts.gla.ac.uk/scottishstudies/ebooks/miorunmor.htm Accessed 30 September 2008.

Broun, D. 1999. A New Look at the Gesta Annalia attributed to John of Fordun. Pp. 9-30. In B E Crawford (Ed.). Church, Chronicle and Learning in Medieval and Early Renaissance Scotland. Mercat press, Edinburgh, UK. 239 pp.

Brown, K. and others (Eds.), 2007. The Records of the Parliaments of Scotland. Available online at http//:www.rps.ac.uk Accessed 16 April 2008.

Brown, M. 2004. The Wars of Scotland 1214-1371. EUP, Edinburgh, UK. 379 pp.

Campbell, B.M.S. 2008. Nature as Historical Protagonist. The Tawney Memorial Lecture 2008. Online at http://www.yadayada.co.uk/podcasts/Blackwell/video/Tawney2008/index.html Accessed 9 November 2008. 
Croft Dickinson, W. 1960. Surdit de Sergaunt. Scottish Historical Review 39: 170-175.

Crowley, T.J. and Lowery, T.S. 2000. How Warm Was the Medieval Warm Period? Ambio 29:51-54.

Dodgshon, R.A. 1998. From Chiefs to Landlords. Social and Economic Change in the Western Highlands and Islands, c.1493-1820. EUP, Edinburgh, UK. 265 pp.

Duffy, S. 2007. The prehistory of the galloglass. Pp. 3-23, In S. Duffy (Ed.). The World of the Galloglass. Kings, warlords and warriors in Ireland and Scotland, 1200-1600. Four Courts Press, Dublin, Ireland. 219 pp.

Duffy, S. 2008. The Galloglass Project, online at http://www.tcd.ie/CISS/galloglass.php; accessed 8 November 2008.

Duncan, A.A.M. (Ed.). 1988. Regesta Regum Scotorum, v, The Acts of Robert I. EUP, Edinburgh, UK. 786 pp.

Edwards, K.J., Borthwick, D., Cook, G., Dugmore, A.J., Mairs, K-A., Church, M.J., Simpson, I.A. and Adderley, W.P. 2005. A Hypothesis-Based Approach to Landscape Change in Suðuroy, Faroe Islands. Human Ecology 33:621-650.

Grant, A. 1984. Independence and Nationhood. Scotland 1306-1469. Edward Arnold (Publishers) Ltd., London, UK. 248 pp.

Jillings, K. 2003. Scotland's Black Death. The Foul Death of the English. Tempus Publishing Ltd, Stroud, UK. 192 pp.

Jordan, W. C. 1996. The Great Famine. Northern Europe in the Early Fourteenth Century. Princeton University Press, Princeton, USA. 317 pp.

Kates, R.W., J.H. Ausubel and M. Berberian, M. (Eds). 1985. Climate Impact Assessment: Studies of the Interaction of Climate and Society. John Wiley and sons, Chichester, UK. $625 \mathrm{pp}$.

Kershaw, I. 1973. The Great Famine and agrarian crisis in England 1315-22. Past and Present 59: 3-50.

Kingston, S. 1999. Trans-Insular Lordship in the Fifteenth Century. Pp 35-49. In T.M.Devine and J.F.McMillan (Eds), Celebrating Columba. Irish-Scottish Connections 597-1997. John Donald Publishers Ltd, Edinburgh, UK. 162 pp.

Kingston, S. 2004. Ulster and the Isles in the Fifteenth Century: the Lordship of Clann Domhnaill of Antrim. Four Courts Press, Dublin, Ireland. 256 pp.

Macpherson, D. et al., (Eds). 1814. Rotuli Scotiae in Turri Londiniensi et in Domo Capitulari Westmonasteriensi Asservati, vol. 1. London, UK. 
McCormick, F. 1998. Calf slaughter as a response to marginality. Pp. 49-51, In C.M Mills and G. Coles (Eds), Life on the Edge - Human Settlement in Marginal Areas. Oxbow Books, Oxford, UK. 188 pp.

McDonald, R.A. 1997. The Kingdom of the Isles. Scotland's Western Seaboard c.1100c.1336. Tuckwell Press, East Linton, UK. 280 pp.

McGovern, T.H., Vésteinsson, O., Fridriksson, A., Church M., Lawson, I., Simpson, I.A., Einarsson, A., Dugmore, A., Cook, G., Perdikaris, S., Edwards, K. J., Thomson, A.M., Adderley, W.P., Newton A., Lucas, G., Edvardsson, R., Aldred, O. and Dunbar, E. 2007. Landscapes of Settlement in Northern Iceland: Historical Ecology of Human Impact \& Climate Fluctuation on the Millennial Scale. American Anthropologist 109:27-51.

Morrison, I. 2001. Climate. Pp. 99-101, In M. Lynch (Ed.). The Oxford Companion to Scottish History. OUP, Oxford, UK. 732 pp.

Nicholls, K. 2007. Scottish Mercenary Kindreds in Ireland, 1250-1600. Pp. 86-105. In S. Duffy (Ed.). The World of the Galloglass. Kings, Warlords and Warriors in Ireland and Scotland, 1200-1600. Four Courts Press, Dublin, Ireland. 219 pp.

Oram, R.D. 1999. Alexander Bur, Bishop of Moray, 1369-1397. Pp. 195-213, In B.E. Crawford (Ed.). Church, Chronicle and Learning in Medieval and Early Renaissance Scotland. Mercat Press, Edinburgh, UK. 239 pp.

Oram, R.D. 2008. "It cannot be decernit quha are clean and quha are foulle." Responses to Epidemic Disease in Sixteenth- and Seventeenth-century Scotland. Renaissance and Reformation 30.4: 13-39.

Oram, R.D. and Ross, A.I. 2006. Brodick Castle, Arran and Lordship in the Clyde Estuary. A Report Prepared for Addyman Archaeology and the National trust for Scotland. 83 pp. Parry, M.L. 1975. Secular climatic change and marginal agriculture. Transactions of the Institute of British Geographers 64: 5-11.

Parry, M.L. 1985. The impact of climatic variations on agricultural margins. Pp. 351-368, In T.W. Kates, J.H. Ausubel and M. Berberian (Eds), Climate Impact Assessment. John Wiley and Sons, Chichester, UK. 625 pp.

Penman, M. 2004. David II. Tuckwell Press, East Linton, UK. 480 pp.

Rogers, C. (Ed.), 1880. Rental Book of the Cistercian Abbey of Cupar-Angus. 2 vols. Grampian Club, London, UK. $372+378$ pp.

Ross, A. 2003, The lords and lordship of Glencarnie. Pp. 159-174. In S. Boardman and A. Ross (Eds). The Exercise of Power in Medieval Scotland c.1200-1500. Four Courts Press, Dublin, Ireland. $240 \mathrm{pp}$. 
Ross, A. 2006. Scottish environmental history and the (mis)use of soums. Agricultural History Review 54 pt. 2: 213-228.

Simms, K. 2000. From Kings to Warlords. Boydell, Woodbridge, UK. 191 pp.

Simms, K. 2007. Images of the galloglass in poems to the MacSweeneys. Pp. 106-123. In S.

Duffy (Ed.). The World of the Galloglass. Kings, Warlords and Warriors in Ireland and

Scotland, 1200-1600. Four Courts Press, Dublin, Ireland. 219 pp.

Simpson, I.A., Adderley, W.P., Guðmundsson, G., Hallsdóttir, M., Sigurgeirsson, M.Á., and

Snæsdóttir, M. 2002. Land management for surplus grain production in early Iceland.

Human Ecology 30:423-443.

Skene, F.J.H. (Trans.). 1872. John of Fordun's Chronicle of the Scottish Nation, vol. 2.

Edinburgh: Historians of Scotland series. 492 pp.

Spinage, C.A. 2003. Cattle Plague. A History. Kluwer Academic, London, UK. 770 pp.

Thomson, J.M. (Ed.). 1882. Registrum Magni Sigilli Regnum Scotorum, vol. 1. H.M.

General Register House, Edinburgh, UK.

Tipping, R. 1998. Cereal cultivation on the Anglo-Scottish Border during the "Little Ice Age". Pp. 1-11 In C.M. Mills and G. Coles (Eds), Life on the Edge - Human Settlement in Marginal Areas. Oxbow Books, Oxford, UK. 188 pp.

Tipping, R. 1999. Towards an environmental history of the Bowmont Valley and the northern Cheviot Hills. Landscape History, 20: 41-50.

Tipping, R. 2004. Palaeoecology and political history: evaluating driving forces in historic landscape change in southern Scotland. Pp. 11-20, In, I.D. Whyte, and A.J.L. Winchester (Eds), Society, Landscape and Environment in Upland Britain. University of Exeter Press, Exeter, UK. 174 pp.

Vinther, B.M., Johnsen, S.J., Andersen, K.K., Clausen, H.B. and Hansen, A.W. 2003. NAO signal recorded in the stable isotopes of the Greenland icecores. Geophysical Research Letters 30, 1387.

Watt, D.E.R. and others (Eds), 1987. Walter Bower, Scotichronicon. Vol. 8. AUP, Aberdeen, UK. 409 pp.

Watt, D.E.R. and others (Eds), 1996. Walter Bower, Scotichronicon. Vol. 7. AUP, Aberdeen, UK. 557 pp.

Woolf, A. 2007. A dead man at Ballyshannon. Pp. 77-85. In S. Duffy (Ed.). The World of the Galloglass. Kings, Warlords and Warriors in Ireland and Scotland, 1200-1600. Four Courts Press, Dublin, Ireland. 219 pp.

Zeigler, P. 2003. The Black Death. $3^{\text {rd }}$ edition. Sutton Publishing Ltd, Stroud, UK. 281 pp. 


\section{Figure captions}

Figure 1: Territorial Expansion of Scottish Clans and Kindreds in the Central Highlands of Scotland post AD 1296.

Figure 2: Long-term climate proxies AD 1000 - AD 2000 for the exotropical Northern Hemisphere and North Atlantic: (a) normalised simple mean of four dendroclimate sequences showing deviation of summer temperature from mean (AD 1601- AD 1974) summer temperature (resampled data after Briffa, et al., 2000); (b) Winter $\delta^{18} \mathrm{O}$ data from DYE-3 ice core of Greenland Ice Cap Summit (Adderley and Simpson, 2006; Vinther, Pers. Comm.; Vinther, et al., 2003) and (c) Unweighted aggregate of fifteen Northern Hemisphere proxies annual deviations from long-term mean (Crowley and Lowery, 2000). All data plotted as 10Year Moving Averages. 


\section{Expansion of kin groups in 14th century Highland Scotland}

Orkney

Islands

Outer

Hebrides

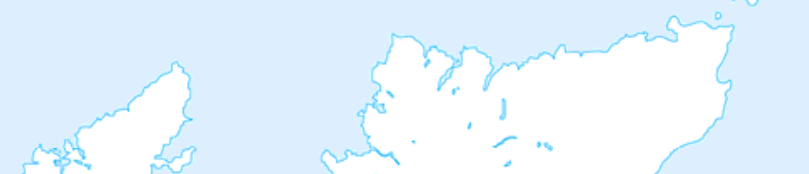

Hestides

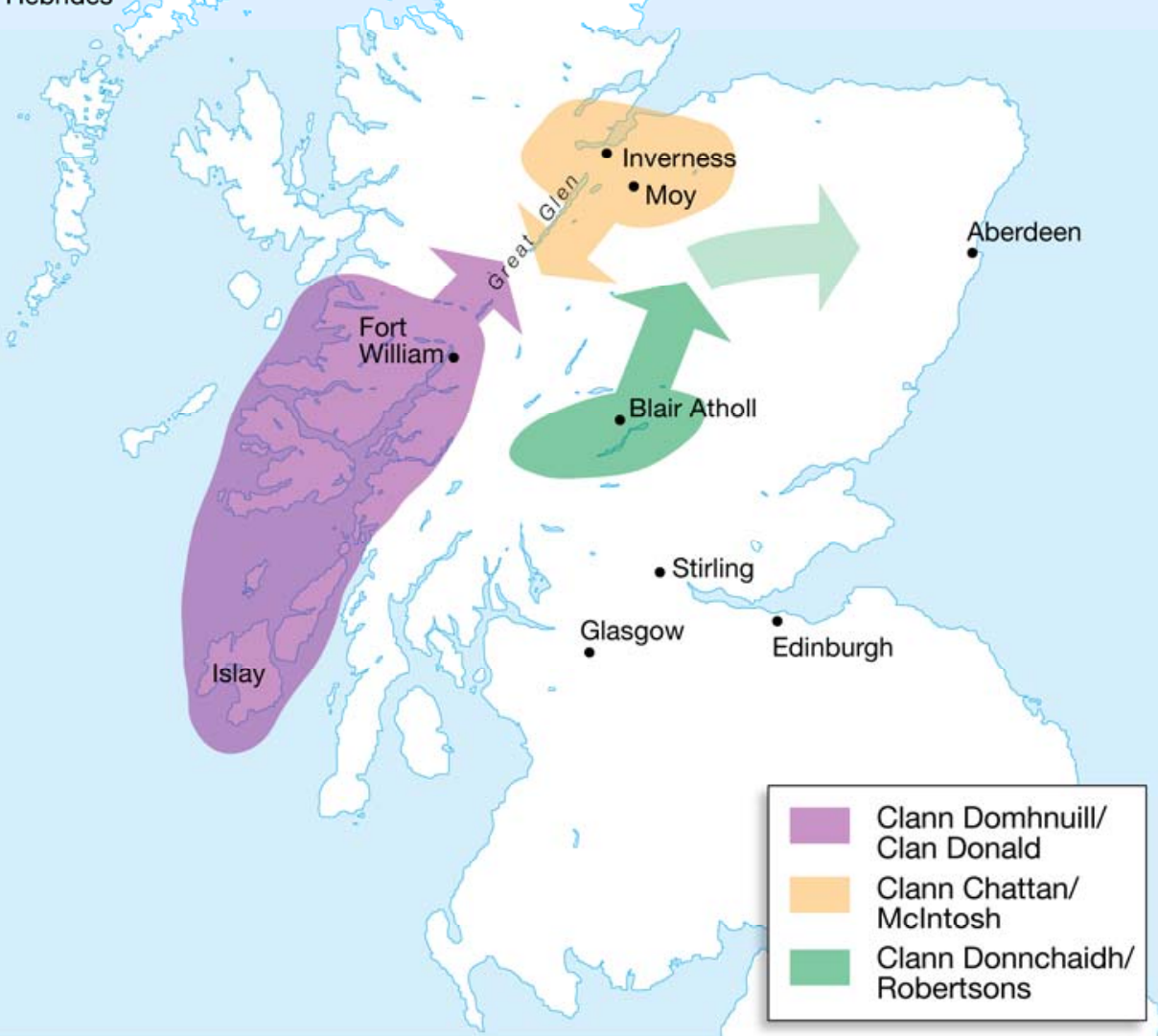



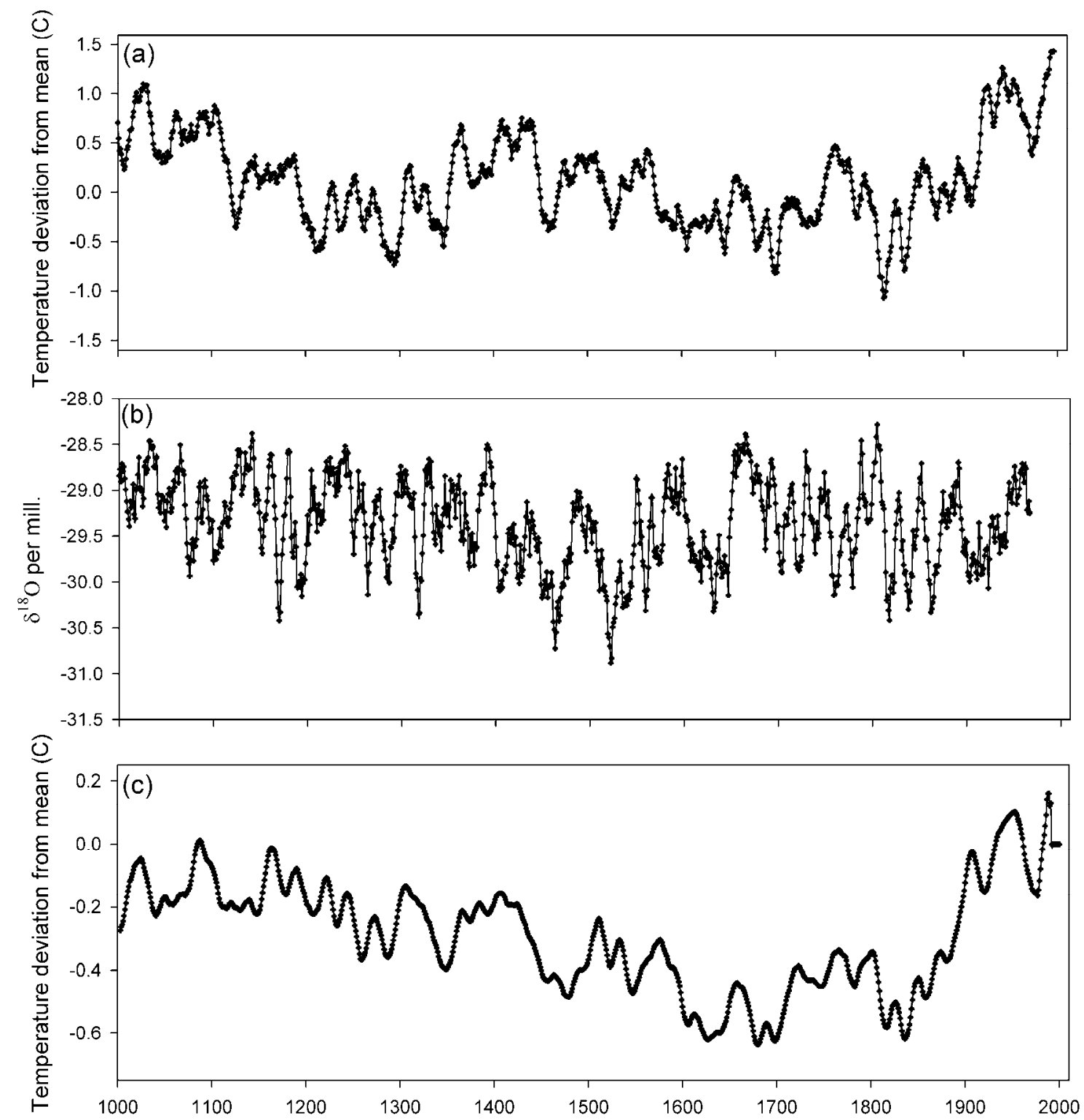